\title{
Characterization of Naturally Occurring Radioactive Material (NORM) Generated from the Lower Cretaceous Carbonate Formations in the Arabian Peninsula and Gulf
}

\author{
Francesco Arneodo', Marco Balata'2, Mohamed Lotfi Benabderrahmane', Gianmarco Bruno', Adriano Di Giovanni', \\ Osama Fawwaz', Matthias Laubenstein'2, Laura Manenti' ${ }^{1}$, Stefano Nisi², and Rüdiger B. Richter ${ }^{3,4}$
}

\author{
${ }^{1}$ New York University Abu Dhabi, Saadiyat Campus, United Arab Emirates \\ ${ }^{2}$ Laboratori Nazionali del Gran Sasso, Assergi L'Aquila, Italy \\ ${ }^{3}$ BAUER Resources, Germany \& BAUER Emirates Environment Abu Dhabi, Abu Dhabi, United Arab Emirates \\ ${ }^{4}$ Chair of Mineral Processing, Montanuniversität Leoben, Leoben, Austria
}

Received July 3, 2020; accepted July 10, 2020; published online August 3, 2020

\begin{abstract}
For most of the petroleum reservoirs in the world, the impact of the mother nuclides such as uranium-238 on the deposition of radioactive materials a.k.a. NORM from the formation and particularly as mineral scales adherent to tubulars and other equipment is considered insignificant. Uranium is regarded as insoluble in the reservoir formation and the prevailing understanding is that dissolved radium is not generated necessarily by $U$ and Th in solution. Consequently, "uranium scale", as a technical term, seems to be non-existent in the oil and gas industry. However, gamma spectroscopy and chemical analysis of NORM scale samples of carbonate origin, performed in the course of this research, has proven that they actually can contain uranium. A fundamental relationship between uranium and vanadium in scales is presumed. The highest specific activity of ${ }^{238} \mathrm{U}$ in scale analyzed with gamma spectroscopy was at $11.4[\mathrm{~Bq} / \mathrm{g}]$ and supplementary chemical analysis has shown concentrations of up to 740 ppm total uranium and up to 260 ppm vanadium.
\end{abstract}

Keywords: NORM, Uranium scale, Oil \& gas industry, Gamma ray spectroscopy, Uranyl minerals, Carbonate scale

O. Fawwaz $(\bowtie)$

New York University Abu Dhabi,

Saadiyat Campus, United Arab Emirates

osama.fawwaz@nyu.edu

Dipl.-Ing. Dr.mont. R. B. Richter, MSRP $(\varangle)$

BAUER Resources, Germany \& BAUER Emirates Environment Abu Dhabi,

Abu Dhabi, United Arab Emirates

ruediger.richter@bauer.de; drruedigerrichter9@gmail.com
Charakterisierung von natürlich vorkommendem radioaktivem Material (NORM) aus den Karbonatformationen der unteren Kreidezeit auf der Arabischen Halbinsel und im Golf

Zusammenfassung: In den meisten Erdölreservoirs der Erde wird der Einfluss der Mutternuklide, wie Uran-238, bei der Ablagerung von radioaktivem Material (NORM) aus der Lagerstätte und insbesondere bei der Ausbildung von kesselsteinartigen mineralischen Ablagerungen, den sogenannten "Scales”, die an Gestängen und Ausrüstung anhaften, als vernachlässigbar angesehen. In der Lagerstättengeologie etwaig vorhandenes Uran wird als unlöslich betrachtet und die vorherrschende Meinung ist, dass gelöstes Radium nicht notwendigerweise durch $U$ und Th in Lösung erzeugt wird. Folglich kommt der Begriff „UranScale" im Vokabular der Öl- und Gasindustrie überhaupt nicht vor. Eine gammaspektroskopische und chemische Analyse von Scale-Proben, die im Zuge dieser Forschung durchgeführt wurde, hat jedoch gezeigt, dass Uran, insbesondere in mineralischen Ablagerungen karbonatischen Ursprungs, durchaus vorhanden sein kann. Eine grundlegende Beziehung zwischen Uran und Vanadium in den karbonatischen „Scales" liegt dabei nahe. Die höchste spezifische Aktivität von ${ }^{238} \mathrm{U}$, die mittels Gammaspektroskopie analysiert wurde, lag bei 11,4 [Bq/g], und eine ergänzende chemische Analyse ergab Konzentrationen von Gesamturan bis zu 740 ppm sowie bis zu 260 ppm Vanadium.

Schlüsselwörter: NORM, Uran-Scale, Öl- und Gasindustrie, Gammaspektroskopie, Uranylminerale, Karbonatische Scales 


\section{Introduction}

Naturally Occurring Radioactive Material (NORM), as a characteristic oil and gas waste, is usually generated in the stage of production, but occasionally also during drilling of exploration wells. The presence of NORM in the oil and gas industry has been reported earlier by various authors [1-5]. The source of NORM are radionuclides and particularly their water-soluble radiochemical compounds which exist naturally in the geological formation of the hydrocarbon reservoir. The primary radioisotopes of concern are of the uranium-radium decay series $\left({ }^{238} \mathrm{U}\right)$, the thorium $\left({ }^{232} \mathrm{Th}\right)$ decay series and potassium $\left({ }^{40} \mathrm{~K}\right)$ which occur freely in the earth's crust $[6,7]$. Not frequently reflected for the evaluation of NORM is the actinium $\left({ }^{235} \mathrm{U}\right)$ decay series [8]. Radioisotopes would naturally be in secular equilibrium if remaining undisturbed for a long enough timeline, but owing to the possible migration of some radionuclides into a mineral matrix and getting deposited at different locations, these radionuclides may become "unsupported", and hence have an activity different from their parents in the decay chain [9]. The concentrations of uranium and thorium in the earth's crust is 4.2 and $12.5 \mathrm{ppm}$, respectively [10]. Both won't appear, as per the prevailing opinion, in significant quantities in NORM samples, because they are commonly considered relatively stable, which means that they mainly occur in form of water-insoluble minerals [11].

Water-soluble compounds of naturally occurring radionuclides, particularly radium compounds, throughout their passage via naturally radioactive geological stratigraphic horizons such as bedrock and shale will leach into the formation water [12]. This is particularly the case in the Middle East, where carbonates and sandstone prevail. Water comes to the surface along with the pumped crude as an oil/produced water mixture, where the dissolved mineral salts precipitate and form less soluble minerals in scales but also in sedimentation areas as sludge [13], as shown in Fig. 1.

The main types of NORM from the oil and gas industry as shown in Fig. 1 are, therefore:

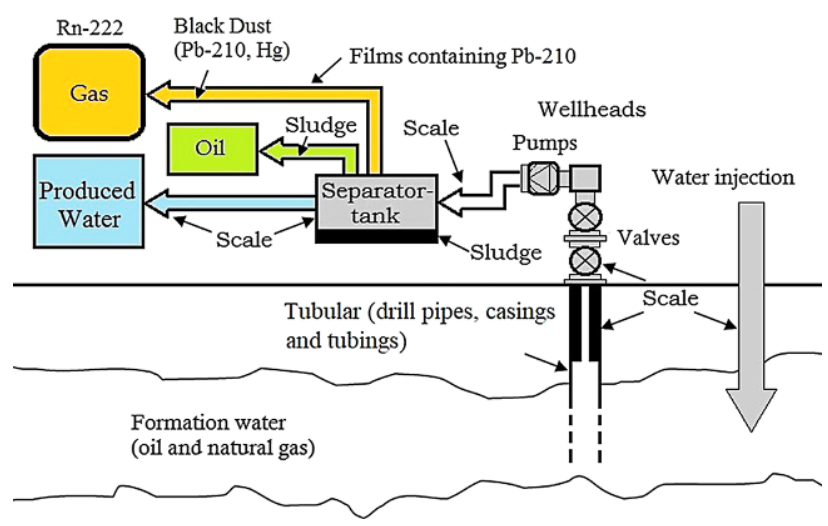

Fig. 1: Typical pathways of NORM accumulation in the oil and gas industry (modified from [14])
- Mineral scales, deposits and thin films (radon progeny) accumulate in plant equipment and particularly adherent to tubular (drill pipes, casings and tubulars); and

- Petroleum hydrocarbon (PHC)-sludge and scrapings from cleaning and pigging activities, which contain radioactive mineral solids.

\subsection{Mineral Scale}

Scale appears as a mineral layer accumulated inside pipes, separators, filters, pumps, wellheads (aka. Christmas trees) and other equipment, as a result of precipitating newly formed (formerly soluble) radionuclide compounds in the produced water. Precipitation is mainly due to changes in pressure and temperature [7], but mechanical impacts also play a role and the amount of the precipitate depends on the physical and chemical properties of the produced water (brine) [15] such as salinity, or pH level [16]. The highest concentrations of NORM are typically found in scale deposits that form under certain physical and chemical conditions when dissolved radionuclide compounds co-precipitate together with barite and celestite $\left(\mathrm{BaSO}_{4}\right.$ and $\mathrm{SrSO}_{4}$, respectively) and/or aragonite $\left(\mathrm{CaCO}_{3}\right)$. These sulfates and carbonate, after generation from the minerals dissolved in the brine/produced water, form insoluble scales but also deposits of high density (often confused with mineral hardness), on the inside of tubulars and production or exploration equipment. Just like calcium, strontium and barium, radium also belongs to the alkaline earth metals (2nd group of the PSE) and hence radium has geochemical affinities to similar elements. It co-precipitates with them forming radium sulfate $\left(\mathrm{RaSO}_{4}\right)$ and particularly mixed sulfates within the $\mathrm{Ra}-\mathrm{Ba}, \mathrm{Ra}-\mathrm{Sr}$ and the Ra-Ba-Sr system. These sulfate scales commonly do not contain uranium. However, under alkaline conditions radium carbonate $\left(\mathrm{RaCO}_{3}\right)$ in particular, but also radium silicate $\left(\mathrm{RaSiO}_{3}\right)$ may be generated [17-19]. Under these correspondingly alkaline conditions the formation of "uranium scale" occurs as shown as a result of this research.

\subsection{NORM Sludge}

Sludge is an oily residue that accumulates at the bottom of storage tanks and other production equipment, particularly in separators. Sludge is made of deposits from heavy hydrocarbons, tight emulsions, produced formation sand and small quantities of corrosion and flaking debris that settle out of suspension in some field equipment [13]. Sludge from pipeline pigging is also addressed as scrapings. NORM in sludge accumulates when radium coprecipitates with silicates and carbonates $[9,20,21]$. The specific activity of radium-226 in sludge can reach values of up to $3500 \mathrm{~Bq} / \mathrm{g}$ [22]. 


\subsection{Lead Films}

Films, as shown in Fig. 1, are very thin layers that contain mostly the daughter nuclides of radon $\left({ }^{222} \mathrm{Rn} ; \mathrm{t}_{1 / 2}=3.8\right.$ days) such as bismuth $\left({ }^{214} \mathrm{Bi} ; t_{1 / 2}=19.9 \mathrm{~min}\right)$, lead $\left({ }^{210} \mathrm{~Pb}\right.$; $\mathrm{t}_{1 / 2}=22.2$ years) and polonium ( ${ }^{210} \mathrm{Po} ; \mathrm{t}_{1 / 2}=138.4$ days). Highly variable ranges of specific activities were measured for scales and can be as high as $15,000 \mathrm{~Bq} / \mathrm{g}$ for ${ }^{226} \mathrm{Ra}$ [22]. ${ }^{210} \mathrm{~Pb}$ and ${ }^{210} \mathrm{Po}$ are also found in films inside gas pipes, gas/oil separators, liquid natural gas storage tanks, in sludge accumulating in tank bottoms, dehydration vessels, and in waste pits in addition to crude oil pipeline scrapings [11].

\subsection{Black Dust}

Black dust (black powder), as a corrosion product of pipe material together with possibly adhered lead films in gas transmission pipelines, commonly contains ${ }^{210} \mathrm{~Pb}$ but also mercury, which is associated to thiols (mercaptans) in the gas reservoir or condensate. These waste types are not subject of this paper which focusses in particular on mineral scales from oil production and exploration.

\subsection{Hazards of NORM}

Radioactive wastes associated with the exploration and production of oil and gas are considered carcinogenic, mutagenic and teratogenic; they are harmful to humans, animals and the environment [23]. These NORM wastes shall be managed in such a way that they do not affect human health and the environment. More recent technical options for treatment, removal and decontamination of NORM- and TENORM-contaminated equipment and debris were published earlier [17, 24-26]. TENORM, as a technical term, describes in particular technologically enhanced NORM, which is rather generated in specific downstream operations such as ethylene cracking etc. than in offshore operations.

\subsection{Objective of this Paper}

The objective of this paper is the characterization of NORM scales from carbonate-rich limestone dominated geological formations which consequently will have a different radiochemical and chemical composition, in particular, the formation of 'uranium scale', in contrast to NORM scales generated from other facies, as mentioned above.

\section{Theory}

\subsection{Existence and Origin of Soluble Uranyl Minerals in Carbonate Formation Rocks}

The Lower Cretaceous Formations in the Arabian Peninsula and Gulf appear to a high extent to be of carbonate origin [27-30]. From the relevant literature concerning the appearance of NORM-scales, it corresponds to the general view, that usually only the daughter nuclides of the uranium $\left({ }^{238} \mathrm{U}\right)$, thorium $\left({ }^{232} \mathrm{Th}\right)$ and the actinium $\left({ }^{235} \mathrm{U}\right)$ decay series are present. Owing to the low solubility of uranium compounds in water such as tri-uranium octoxide $\left(\mathrm{U}_{3} \mathrm{O}_{8}\right)$ in the formation concerned $[7,31]$ and the current understanding, that dissolved radium is not generated by $U$ and Th in solution [32]. Consequently, the characterization as "radium-rich scale", a.k.a. "radium scale" $[6,33]$ is widely used, whilst the term 'uranium scale' seems to be fundamentally unknown in the oil and gas industry.

Uranium in its compounds usually exists in valences of $+2,+3,+4,+5$, and +6 . In aqueous solution, only ions having a valence of +4 and +6 , exist. The redox behaviour of uranium allows to transfer tetravalent into hexavalent uranium, simply by oxidation in an aqueous solution:

$$
\mathrm{U}^{4+}+2 \mathrm{H}_{2} \mathrm{O} \rightarrow\left(\mathrm{UO}_{2}\right)^{2+}+4 \mathrm{H}^{+}+2 e^{-}
$$

$\mathrm{U}^{6+}$ is the most stable species of uranium and exists predominantly as uranyl cation $\left(\mathrm{UO}_{2}\right)^{2+}$, whilst in sodic alkaline carbonate enriched solutions, $\mathrm{U}^{6+}$ is available as uranyl tricarbonate complex $\left[\mathrm{UO}_{2}\left(\mathrm{CO}_{3}\right)_{3}\right]^{4-}$ (Fig. 2).

The most plausible reason for the migration of commonly stable uranium oxides into the environment and the generation of uranium-bearing NORM scales is the formation of uranyl carbonate and hydroxide minerals and their ability to be more water-soluble as mixed complex ions such as $\left(\mathrm{UO}_{2}\right)_{2} \mathrm{CO}_{3}(\mathrm{OH})_{3}{ }^{-}[35,36]$.

In particular, the presence of the carbonate ion $\mathrm{CO}_{3}{ }^{2-}$ has considerably high impact on the solubility of uranium owing to the formation of uranyl carbonate complexes such as uranium dicarbonate $\mathrm{UO}_{2}\left(\mathrm{CO}_{3}\right)_{2}{ }^{2-}$ and uranium tricarbonate $\mathrm{UO}_{2}\left(\mathrm{CO}_{3}\right)_{3}{ }^{4-}$. Whilst the solubility product of Rutherfordine $\left(\mathrm{UO}_{2}\right)_{\mathrm{CO}_{3}}$ with $\mathrm{K}_{\mathrm{sp}}=10^{-16.4}(\mathrm{~mol} / \mathrm{l})^{3}$ is still very low (almost water insoluble), the solubility product of uranium dicarbonate $\mathrm{UO}_{2}\left(\mathrm{CO}_{3}\right)_{2}{ }^{2-}$ with $\mathrm{K}_{\mathrm{sp}}=10^{+20.4}(\mathrm{~mol} / \mathrm{l})^{3}$ and for uranium tricarbonate $\mathrm{UO}_{2}\left(\mathrm{CO}_{3}\right)_{2}{ }^{2-}$ with $\mathrm{K}_{\mathrm{sp}}=10^{+24.2}(\mathrm{~mol} / \mathrm{l})^{3}$ demonstrates excellent solubility in water [37].

Limestone, dolomites and other sedimentary carbonate rocks have been considered earlier as non-uraniferous [37]. However, carbonate-cemented calcretized sediments host large surficial uranium deposits [37-40], where in particular the formation of 'uranovanadates' is considered a major criterion for the genesis of such deposits [41, 42]. Relevant members of the carnotite group and other double salts of the uranyl cation are listed in Table 1.

More recent articles concerning the appearance of uranyl vanadates in carbonates and calcretes, particularly in countries of the Middle East, were published for a study area in Central Jordan by Koury et al. [46]. Pracejus and his co-workers [47] also published a paper concerning tertiary limestone and calcretes in Southern Oman. Consequently, secondary formed uranovanadate minerals may act as a source of soluble uranium in formation water, particularly in a carbonate environment. The solubility of carnotite in carbonated water is about three orders higher than in pure water [48]. Also, the existence of uranyl selenites may play a role in the generation of uranium scales. 

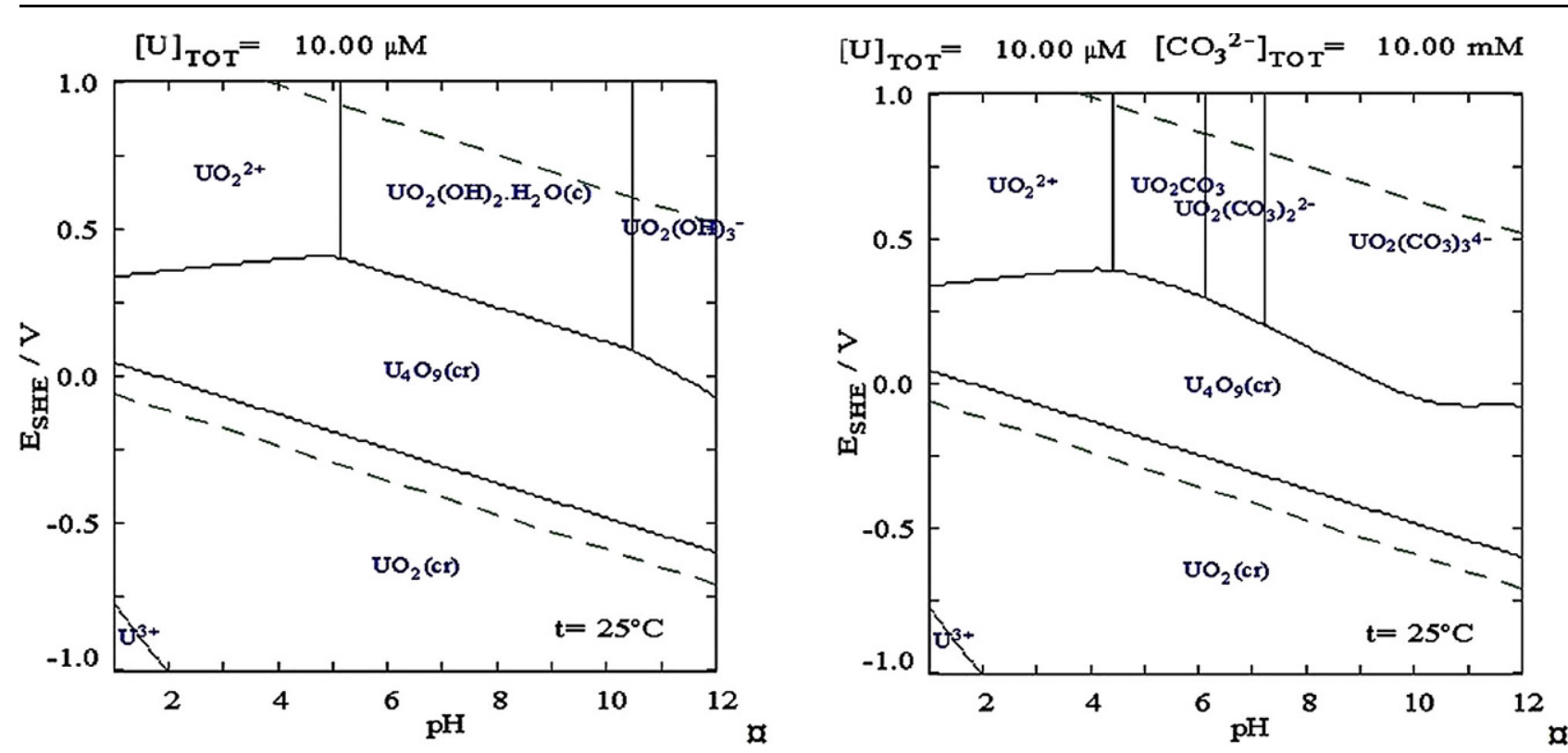

Fig. 2: Pourbaix-diagrams of uranium in water (left) and in a carbonate environment (right) [34]

\begin{tabular}{|lll}
\hline $\begin{array}{l}\text { TABLE } 1 \\
\text { Uranovanadate minerals of the carnotite group and related species [43-45] }\end{array}$ & \\
\hline Mineral Name & Mineralogical Formula (IMA) & Crystal System \\
\hline Carnotite & $\mathrm{K}_{2}\left(\mathrm{UO}_{2}\right)_{2}\left(\mathrm{VO}_{4}\right)_{2} \cdot 2-3 \mathrm{H}_{2} \mathrm{O}$ & Monoclinic \\
\hline Strelkinite & $\mathrm{Na}_{2}\left(\mathrm{UO}_{2}\right)_{2}\left(\mathrm{VO}_{4}\right)_{2} \cdot 6 \mathrm{H}_{2} \mathrm{O}$ & Orthorhombic \\
\hline Tyuyamunite & $\mathrm{Ca}\left(\mathrm{UO}_{2}\right)_{2}\left(\mathrm{VO}_{4}\right)_{2} \cdot 5-8 \mathrm{H}_{2} \mathrm{O}$ & Orthorhombic \\
\hline Metatyuyamunite & $\mathrm{Ca}\left(\mathrm{UO}_{2}\right)_{2}\left(\mathrm{VO}_{4}\right)_{2} \cdot 3-5 \mathrm{H}_{2} \mathrm{O}$ & Orthorhombic \\
\hline Vanuralite & $\mathrm{Al}\left(\mathrm{UO}_{2}\right)_{2}\left(\mathrm{~V}_{2} \mathrm{O}_{8}\right)(\mathrm{OH}) \cdot 11 \mathrm{H}_{2} \mathrm{O}$ & Monoclinic \\
\hline Metavanuralite & $\mathrm{Al}\left(\mathrm{UO}_{2}\right)_{2}\left(\mathrm{VO}_{4}\right)_{2}(\mathrm{OH}) \cdot 8 \mathrm{H}_{2} \mathrm{O}$ & Triclinic \\
\hline Margaritasite & $\left(\mathrm{Cs}, \mathrm{K}_{2} \mathrm{H}_{3} \mathrm{O}\right)_{2}\left(\mathrm{UO}_{2}\right)_{2}\left(\mathrm{VO}_{4}\right)_{2} \cdot \mathrm{H}_{2} \mathrm{O}$ & Monoclinic \\
\hline Sengierite & $\mathrm{Cu}\left(\mathrm{UO}_{2}\right)_{2}\left(\mathrm{VO}_{4}\right)_{2}(\mathrm{OH})_{2} \cdot 6 \mathrm{H}_{2} \mathrm{O}$ & Monoclinic \\
\hline Vanuranylite & $\left(\mathrm{H}_{3} \mathrm{O}\right)_{2}\left(\mathrm{UO}_{2}\right)_{2}\left(\mathrm{VO}_{4}\right)_{2} \cdot 4 \mathrm{H}_{2} \mathrm{O}$ & Monoclinic \\
\hline Curienite & $\mathrm{Pb}\left(\mathrm{UO}_{2}\right)_{2}\left(\mathrm{VO}_{4}\right)_{2} \cdot 5 \mathrm{H}_{2} \mathrm{O}$ & Orthorhombic \\
\hline Francevillite & $\left(\mathrm{Ba}, \mathrm{Pb}_{(}\left(\mathrm{UO}_{2}\right)_{2}\left(\mathrm{VO}_{4}\right)_{2} \cdot 5 \mathrm{H}_{2} \mathrm{O}\right.$ & Orthorhombic \\
\hline Fritzscheite & $\mathrm{Mn}\left(\mathrm{UO}_{2}\right)_{2}\left(\mathrm{PO}_{4}, \mathrm{VO}_{4}\right)_{2} \cdot 10 \mathrm{H}_{2} \mathrm{O}$ & Tetragonal \\
\hline
\end{tabular}

Although their crystal structures (mineralogical habit) has only recently been discovered [49] and being rather unknown in nature, uranyl selenates have high solubility in aqueous solutions and $\mathrm{Se}^{6+}$ is easily reduced to $\mathrm{Se}^{4+}$ under common natural conditions $[50,51]$.

\subsection{Description of the Study Area and Origin of the NORM Samples}

The Upper Jurassic Carbonate Formations (Arab A, B, C and the Upper Arab D) and the Middle Jurassic Araej Formation host the rich oil reservoirs in the Kingdom of Saudi Arabia, the United Arab Emirates (particularly Western Abu Dhabi), the State of Qatar and the Kingdom of Bahrain. Limestone, dolomite and anhydrite are the three major rock types of the Arab Formations [27]. The reservoir conditions in the Araej Formation are dominated by limestone facies [28]. These elder formations are overlaid offshore Central Abu
Dhabi by the Lower Cretaceous Kharaib Formation including the Thamama Group. Particularly Zone 4 of the latter is the most important producer for the giant Upper Zakum oil field. The Thamama Group consists of three discrete porous chalky limestone units, which are each underlain by dense argillaceous limestone [29, 30]. The NORM samples which are subject of this study are entirely assigned to these 'Lower Cretaceous Formations'.

\section{Experimental and Interpretation of Analysis Results}

\subsection{Gamma-ray Spectroscopy}

Gamma-ray spectroscopy (gamma spectroscopy) is a key technology for the quantitative study and analysis of the energy spectra of gamma-ray emitters. The measuring arrangement typically consists of a scintillator that emits 


\begin{tabular}{|lllll|}
\hline \multicolumn{7}{|l|}{$\begin{array}{l}\text { TABLE } 2 \\
\text { Specific activity of }{ }^{226} \text { Radium, }{ }^{214} \text { Lead and }{ }^{214} \text { Bismuth }\end{array}$} & \\
\hline Sr. No & Sample Name & $\begin{array}{l}{ }^{226} \mathrm{Ra} \\
{[\mathrm{Bq} / \mathrm{g}]}\end{array}$ & $\begin{array}{l}{ }^{214} \mathrm{~Pb} \\
{[\mathrm{~Bq} / \mathrm{g}]}\end{array}$ & $\begin{array}{l}{ }^{214} \mathrm{Bi} \\
{[\mathrm{Bq} / \mathrm{g}]}\end{array}$ \\
\hline 1 & SCALE-A-67 & $23.5 \pm 0.3$ & $14.1 \pm 0.3$ & $10.4 \pm 0.4$ \\
\hline 2 & SCALE-A-68 & $8.4 \pm 0.2$ & $5.1 \pm 0.1$ & $2.9 \pm 0.1$ \\
\hline 3 & SCALE-A-73 & $2.9 \pm 0.1$ & $2.04 \pm 0.02$ & $1.42 \pm 0.03$ \\
\hline 4 & SCALE-A-75 & $1.5 \pm 0.2$ & $0.66 \pm 0.02$ & $0.49 \pm 0.03$ \\
\hline 5 & SCALE-B-42 & $50 \pm 1$ & $39 \pm 2$ & $35 \pm 2$ \\
\hline 6 & SCALE-B-44 & $145 \pm 4$ & $110 \pm 3$ & $105 \pm 3$ \\
\hline 7 & SCALE-B-48 & $53 \pm 2$ & $42 \pm 1$ & $39 \pm 1$ \\
\hline 8 & SCALE-B-61 & $51 \pm 2$ & $36 \pm 1$ & $39 \pm 1$ \\
\hline 9 & SCALE-B-63 & $33 \pm 1$ & $25 \pm 1$ & $24 \pm 1$ \\
\hline 10 & SCALE-B-64 & $36 \pm 1$ & $33 \pm 1$ & $32 \pm 1$ \\
\hline
\end{tabular}

\begin{tabular}{|c|c|c|c|}
\hline \multicolumn{4}{|c|}{$\begin{array}{l}\text { TABLE } 3 \\
\text { Specific activity of }{ }^{235} \text { Uranium and }{ }^{234} \text { Thorium }\end{array}$} \\
\hline Sr. No & Sample Name & $\begin{array}{l}{ }^{235} \mathrm{U} \\
{[\mathrm{Bq} / \mathrm{g}]}\end{array}$ & $\begin{array}{l}{ }^{234} \mathrm{Th} \\
{[\mathrm{Bq} / \mathrm{g}]}\end{array}$ \\
\hline 1 & SCALE-A-69 & $0.25 \pm 0.02$ & $5.2 \pm 0.2$ \\
\hline 2 & SCALE-A-70 & $0.46 \pm 0.04$ & $9.5 \pm 0.5$ \\
\hline 3 & SCALE-A-72 & $0.36 \pm 0.04$ & $6.2 \pm 0.4$ \\
\hline 4 & SCALE-A-80 & $0.26 \pm 0.02$ & $4.4 \pm 0.2$ \\
\hline 5 & SCALE-A-82 & $0.35 \pm 0.07$ & $9 \pm 2$ \\
\hline 6 & SCALE-B-34 & $0.41 \pm 0.04$ & $11.5 \pm 0.4$ \\
\hline 7 & SCALE-B-35 & $0.36 \pm 0.01$ & $8.6 \pm 0.4$ \\
\hline
\end{tabular}

a pulse of light when interacting with a gamma-ray, a photomultiplier that converts and amplifies the light pulse into a current pulse, and the subsequent amplifiers and counters. In the course of the present research a Nal(TI) scintillation radiation detector, using a single crystal of thallium doped sodium iodide, and a high purity germanium (HPGe) detector were applied.

\subsubsection{Gamma Spectroscopy Applying a Nal(TI) Scintillation Radiation Detector}

26 scale samples were measured, as collected from the field (slowly dried at ambient temperature), without any further treatment. An ORTEC, $3 \times 3$ inch -905 Series Nal(TI) scintillation radiation detector, coupled to a digiBASE 14-Pin PMT Base, with Integrated Bias Supply, Preamplifier, and MCA with Digital Signal Processing, was used. Sampling was automated for $12 \mathrm{~h}$ acquisition time using the 'MAESTRO Multichannel Analyzer Emulation'. The analysis was carried out using the ORIGIN ${ }^{\circledR} 2018$ graphing and analysis software.
The absolute efficiency of the detector was calculated based on the activity of ${ }^{40} \mathrm{~K}$, using a potassium chloride sample [52], and found to be $5.024 \pm 0.014 \%$ at $1460.82 \mathrm{keV}$. The efficiency curve for the $\mathrm{Nal}(\mathrm{TI})$ detector was produced using GEANT4 simulation [53] and then normalized to match the measured value for ${ }^{40} \mathrm{~K}$.

The detector was calibrated by using a low activity sample, prepared in the lab using "Gas Light Lamp Mantle" containing thorium $\left({ }^{232} \mathrm{Th}\right)$, mixed with organic brown sugar, which was also used for recording the background radiation. It also showed a quite similar geometry to that of the NORM samples. The detector's resolution at $609 \mathrm{keV}$ was $7.90 \pm 0.05 \%$. The radionuclides studied in this work were ${ }^{226} \mathrm{Ra}(1600 \mathrm{y}),{ }^{214} \mathrm{~Pb}(26.8 \mathrm{~min}),{ }^{214} \mathrm{Bi}(19.9 \mathrm{~min}),{ }^{234} \mathrm{Th}(24.1$ days) and ${ }^{235} \mathrm{U}\left(7.038 \times 10^{8} \mathrm{y}\right)$. The spectra produced by the Nal detector indicated no evidence of ${ }^{228} \mathrm{Th}$ or ${ }^{40} \mathrm{~K}$ activity beyond the critical limit.

From 26 samples analyzed, 9 samples had no detectable activity, and hence the activity of any possibly present radioisotope was below detection limits. Ten samples contained ${ }^{226} \mathrm{Ra}$ and its progeny, and seven of the samples contained ${ }^{235} \mathrm{U}$ and ${ }^{238} \mathrm{U}$ but not ${ }^{226} \mathrm{Ra},{ }^{228} \mathrm{Ra}$ or ${ }^{232} \mathrm{Th}$ and their progenies.

Survey of 226-Radium and Its Progeny For this survey, only ${ }^{226} \mathrm{Ra}$ and its progeny were examined, using the $\mathrm{Nal}(\mathrm{TI}) \mathrm{de}-$ tector. The lines of ${ }^{226} \mathrm{Ra}$ at $186.211 \mathrm{keV}(3.64 \%),{ }^{214} \mathrm{~Pb}$ at $351.9321 \mathrm{keV}(35.6 \%)$ and ${ }^{214} \mathrm{Bi}$ at $609.32 \mathrm{keV}$ (45.49\%) were analyzed for specific activity measurement. For closed isotopic systems, the secular equilibrium between the parentdaughter radionuclide can be attained after a period equivalent to approx. 6 times 10 half-lives of the daughter nuclide, where no parent decay occurs [54] ( 20 h in the case of ${ }^{214} \mathrm{Bi}$ ). Comparable activities were noted for ${ }^{214} \mathrm{Bi}$ and ${ }^{214} \mathrm{~Pb}$ for the higher activity samples (5 to 10 times higher).

\begin{tabular}{|c|c|c|c|c|c|c|}
\hline & $\begin{array}{l}{ }^{234} \mathrm{Th} \\
{[\mathrm{Bq} / \mathrm{g}]}\end{array}$ & $\begin{array}{l}{ }^{234} \mathrm{Th} \\
{[\mathrm{Bq} / \mathrm{g}]}\end{array}$ & $\begin{array}{l}{ }^{234 \mathrm{~m}} \mathrm{~Pa} \\
{[\mathrm{~Bq} / \mathrm{g}]}\end{array}$ & $\begin{array}{l}{ }^{234} \mathrm{U} \\
{[\mathrm{Bq} / \mathrm{g}]}\end{array}$ & $\begin{array}{l}{ }^{235} \mathrm{U} \\
{[\mathrm{Bq} / \mathrm{g}]}\end{array}$ & $\begin{array}{l}{ }^{235} \mathrm{U} \\
{[\mathrm{Bq} / \mathrm{g}]}\end{array}$ \\
\hline SCALE-A-72 & $8.9 \pm 0.7$ & $6.2 \pm 0.4$ & $8.2 \pm 0.6$ & $8.6 \pm 0.9$ & $0.42 \pm 0.03$ & $0.36 \pm 0.04$ \\
\hline
\end{tabular}


Fig. 3: ${ }^{226}$ Ra spectrum showing the three lines used for activity calculation

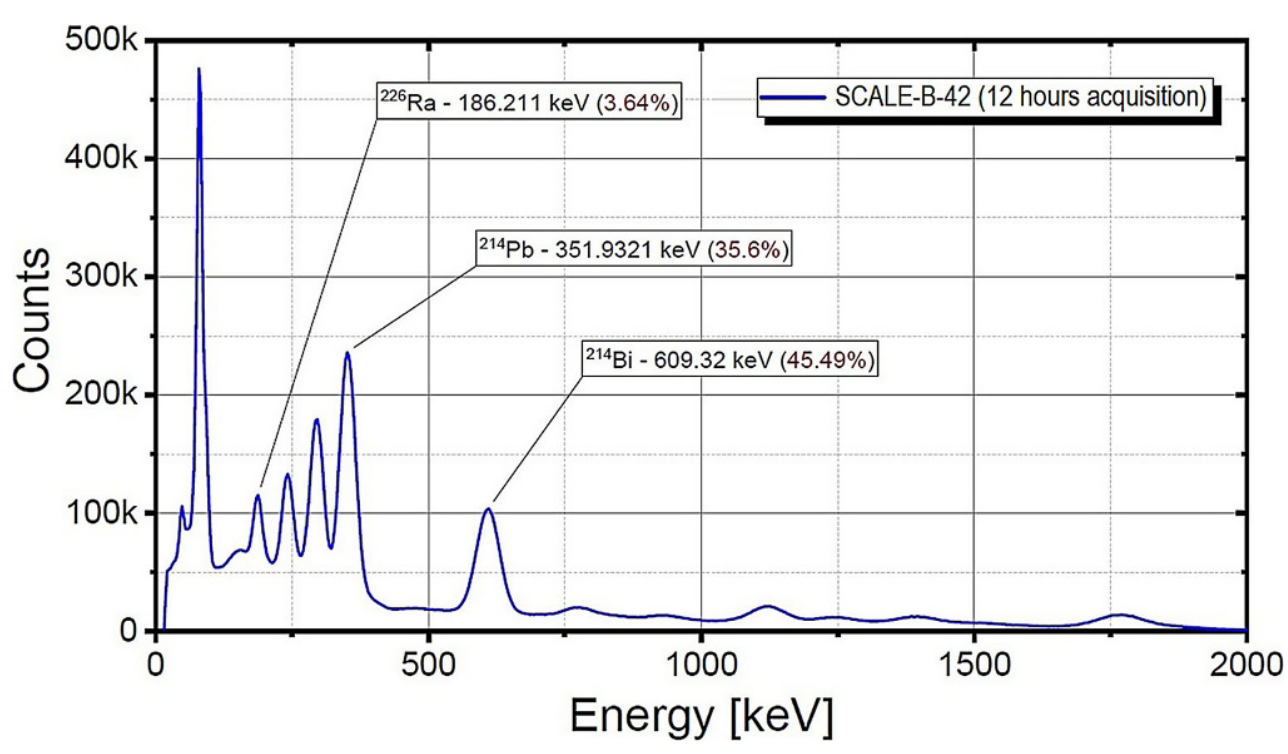

Fig. 4: ${ }^{238 / 235} U$ spectrum showing the two lines used for activity calculation of sample SCALE-B-34

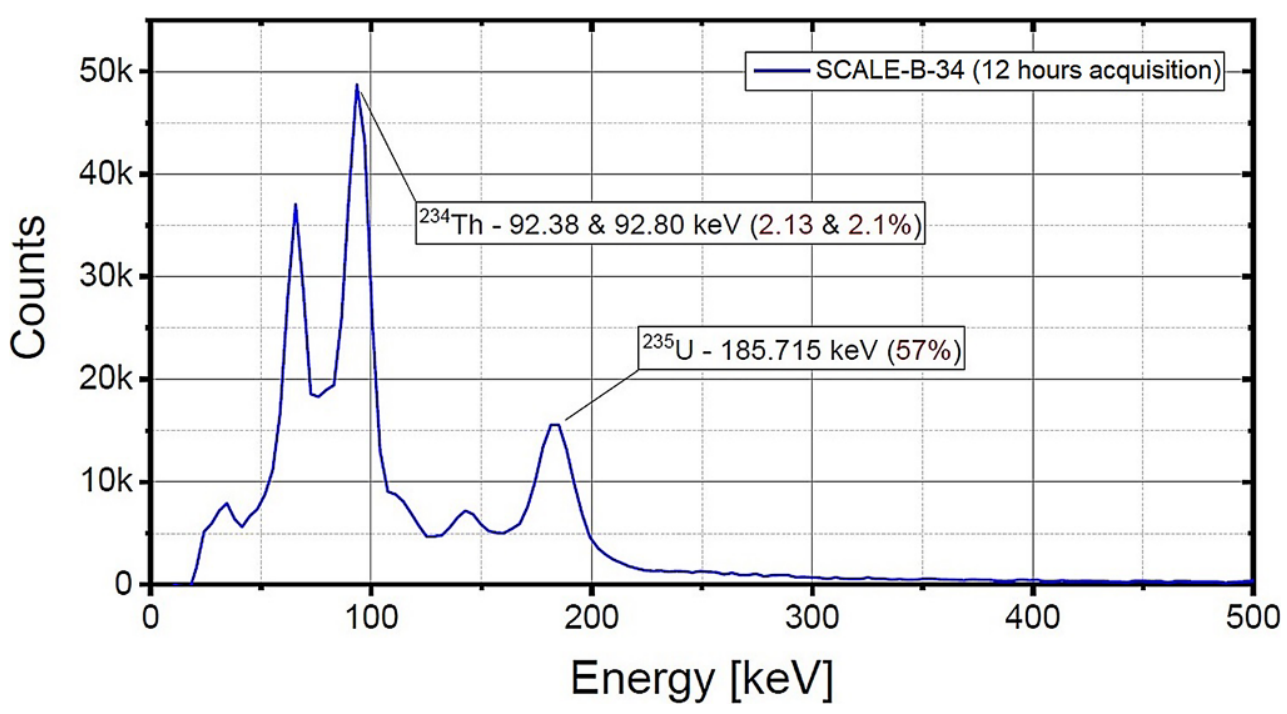

These samples had no measurable activity for the ${ }^{228} \mathrm{Ra}$ progeny (daughters of ${ }^{232} \mathrm{Th}$ ) and ${ }^{40} \mathrm{~K}$. Uncertainties, also shown in Table 2 (and later on, Table 3), are obtained by combining components from peak fitting and the sample's mass measurement.

Previous work studying the equilibrium in NORM samples has shown that ${ }^{226}$ Ra activity was almost always inferred from ${ }^{214} \mathrm{~Pb}$ and ${ }^{214} \mathrm{Bi}[55,56]$. Consequently, a possible interpretation for the higher values obtained could be the interference from ${ }^{235} \mathrm{U}$ line at $185.715 \mathrm{keV}$ (57\%). (Table 2).

In Fig. 3 the ${ }^{226}$ Ra spectrum is shown with the three lines used for activity calculation, using the example of sample SCALE-B-42.

Survey of 235/238-Uranium and Its Progeny No significant activity is present for ${ }^{226} \mathrm{Ra}$ or ${ }^{232} \mathrm{Th}$ and their progenies in these samples. The evaluation of the ${ }^{238} \mathrm{U}$ activity has been done using its daughter ${ }^{234} \mathrm{Th}(24.10 \mathrm{~d})$, a peak that is a combination of the lines 92.38 and $92.80 \mathrm{keV}$ with intensities 2.13 and $2.1 \%$, respectively. It was not possible to use the $1001.03 \mathrm{keV}$ line from ${ }^{234 \mathrm{mPa}}$ which is highly favoured for uranium measurement [57] due to detector resolution and its low intensity $(0.842 \%)$. ${ }^{235} \mathrm{U}$ activity was evaluated using the line at $185.715 \mathrm{keV}$ (57\%). Such a spectrum is usually obtained in water treatment/purification facilities. A similar spectrum was reported for IONEX resin, a material used in filters which is 'highly selective for uranium' ([58]; Table 3).

In Fig. 4 the ${ }^{238 / 235} \mathrm{U}$ spectrum is shown with the two lines used for activity calculation, using the example of sample SCALE-B-34.

\subsubsection{Gamma Spectroscopy Applying a High Purity Germanium (HPGe) Radiation Detector}

Owing to the limited energy resolution of $\mathrm{Nal}(\mathrm{TI})$ detectors, the analysis can be quite difficult and hampered by the 


\begin{tabular}{|lll|}
\hline \multicolumn{1}{|l}{ TABLE 5} \\
HPGe activity results of scale samples A-67 and A-68; Nal(TI) results are in bold for comparison \\
\hline & SCALE-A-67 & SCALE-A-68 \\
\hline${ }^{226} \mathrm{Ra}[\mathrm{Bq} / \mathrm{g}]$ & $14.9 \pm 0.6$ & $3.95 \pm 0.16$ \\
\hline${ }^{226} \mathrm{Ra}[\mathrm{Bq} / \mathrm{g}]$ & $23.5 \pm 0.3$ & $8.4 \pm 0.2$ \\
\hline${ }^{214} \mathrm{~Pb}[\mathrm{~Bq} / \mathrm{g}]$ & $14.1 \pm 0.3$ & $5.1 \pm 0.1$ \\
\hline${ }^{214} \mathrm{Bi}[\mathrm{Bq} / \mathrm{g}]$ & $10.4 \pm 0.4$ & $2.9 \pm 0.1$ \\
\hline${ }^{234} \mathrm{Th}[\mathrm{Bq} / \mathrm{g}]$ & $7.28 \pm 0.39$ & $5.35 \pm 0.29$ \\
\hline${ }^{234} \mathrm{~m} \mathrm{~Pa}[\mathrm{~Bq} / \mathrm{g}]$ & $7.6 \pm 0.8$ & $5.2 \pm 0.5$ \\
\hline${ }^{235} \mathrm{U}[\mathrm{Bq} / \mathrm{g}]$ & $0.34 \pm 0.03$ & $0.24 \pm 0.18$ \\
\hline${ }^{210} \mathrm{~Pb}[\mathrm{~Bq} / \mathrm{g}]$ & $1.83 \pm 0.14$ & $<12$ \\
\hline${ }^{228} \mathrm{Ra}[\mathrm{Bq} / \mathrm{g}]$ & $0.026 \pm 0.009$ & $0.011 \pm 0.004$ \\
\hline${ }^{40} \mathrm{~K}[\mathrm{~Bq} / \mathrm{g}]$ & $<0.057$ & $<0.025$ \\
\hline${ }^{226} \mathrm{Ra}$ was inferred from ${ }^{214} \mathrm{~Pb} \mathrm{\&}{ }^{214} \mathrm{Bi}$, and ${ }^{228} \mathrm{Ra} \mathrm{from}{ }^{228} \mathrm{Ac}$ & \\
\hline
\end{tabular}

TABLE 6

Summary of the samples list and dissolution procedure applied

\begin{tabular}{|c|c|c|c|}
\hline Sample Name & Mass [mg] & Wet digestion procedure & Total Dilution Factor \\
\hline SCALE-A-67 & 0.2745 & \multirow{3}{*}{$\begin{array}{l}5 \mathrm{ml} \text { conc. } \mathrm{HNO}_{3}(69 \% \mathrm{w} / \mathrm{w})+2 \mathrm{ml} \text { conc. } \mathrm{HCl}(37 \% \\
w / w)+0.5 \mathrm{ml} \text { conc. } \mathrm{HF}(49 \% w / w) \text { in ultrasonic bath for } \\
2 \text { days at } 60^{\circ} \mathrm{C}\end{array}$} & 5464 \\
\hline SCALE-A-68 & 0.2639 & & 5684 \\
\hline SCALE-A-72 & 0.2781 & & 5394 \\
\hline
\end{tabular}

natural limitations of the process, especially for multiplet structures where multiple gamma lines sometimes interfere with X-rays in certain peaks. Three of the already measured (with the $\mathrm{Nal}(\mathrm{TI})$ detector) scale samples (A-67, A-68 and A-72) were re-measured at the 'Laboratori Nazionali del Gran Sasso (LNGS)', using HPGe (high purity germanium) GeDSG detector for an acquisition time of more than $24 \mathrm{~h}$ (Tables 4 and 5).

The activity measured with the Nal (TI) detector was close to the results of the HPGe measurement and several times in agreement. Good conformity with the results of the HPGe has been shown in particular for well isolated lines, having less neighbouring interference. The more recent literature refers to examples of good agreement [58], but also to some discrepancies in other cases [59]. Fig. 5 shows the spectra of samples measured with both the $\mathrm{Nal}(\mathrm{TI})$ and the HPGe detector.
Fig. 5: Spectra of samples measured with both the Nal( $\mathrm{TI})$ and the HPGe detector
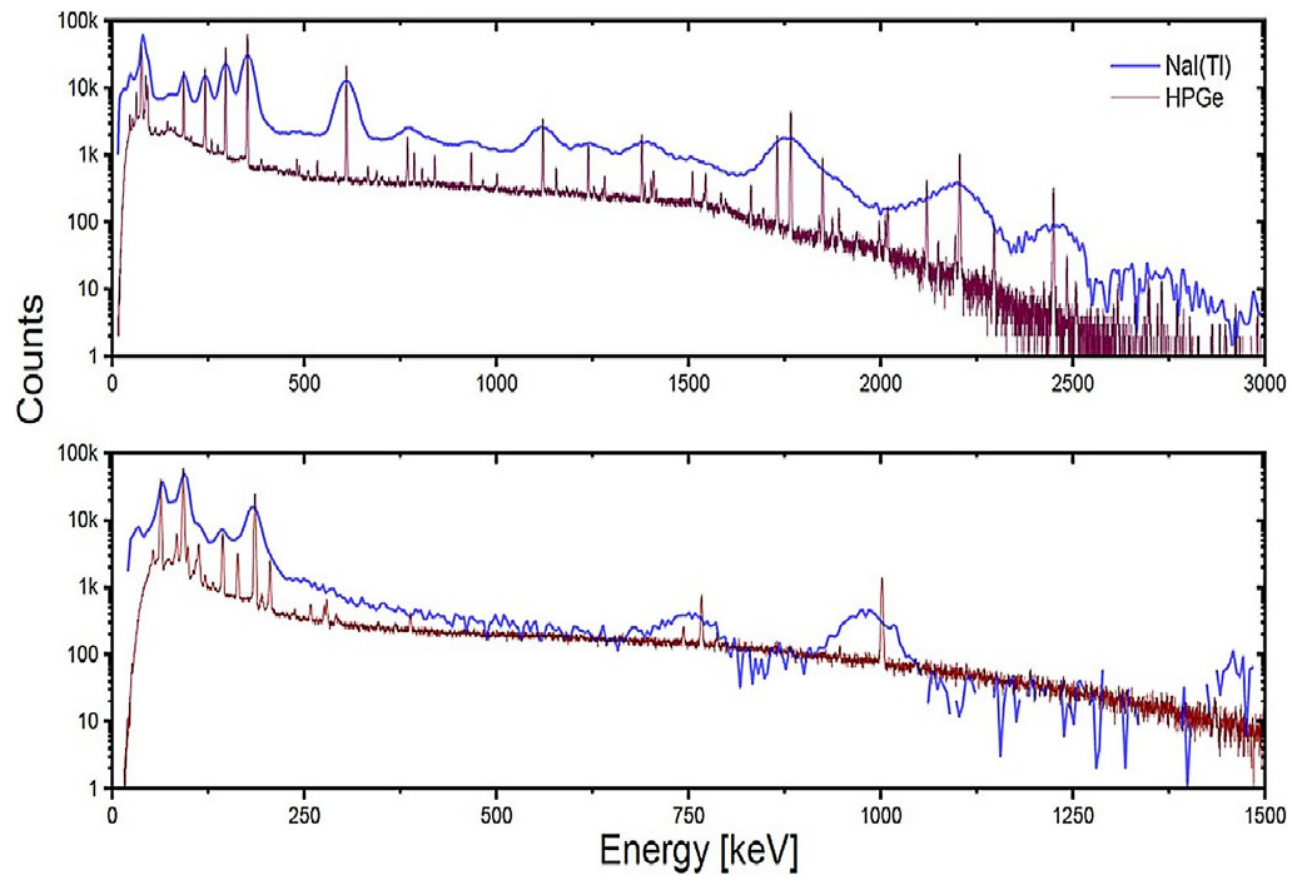


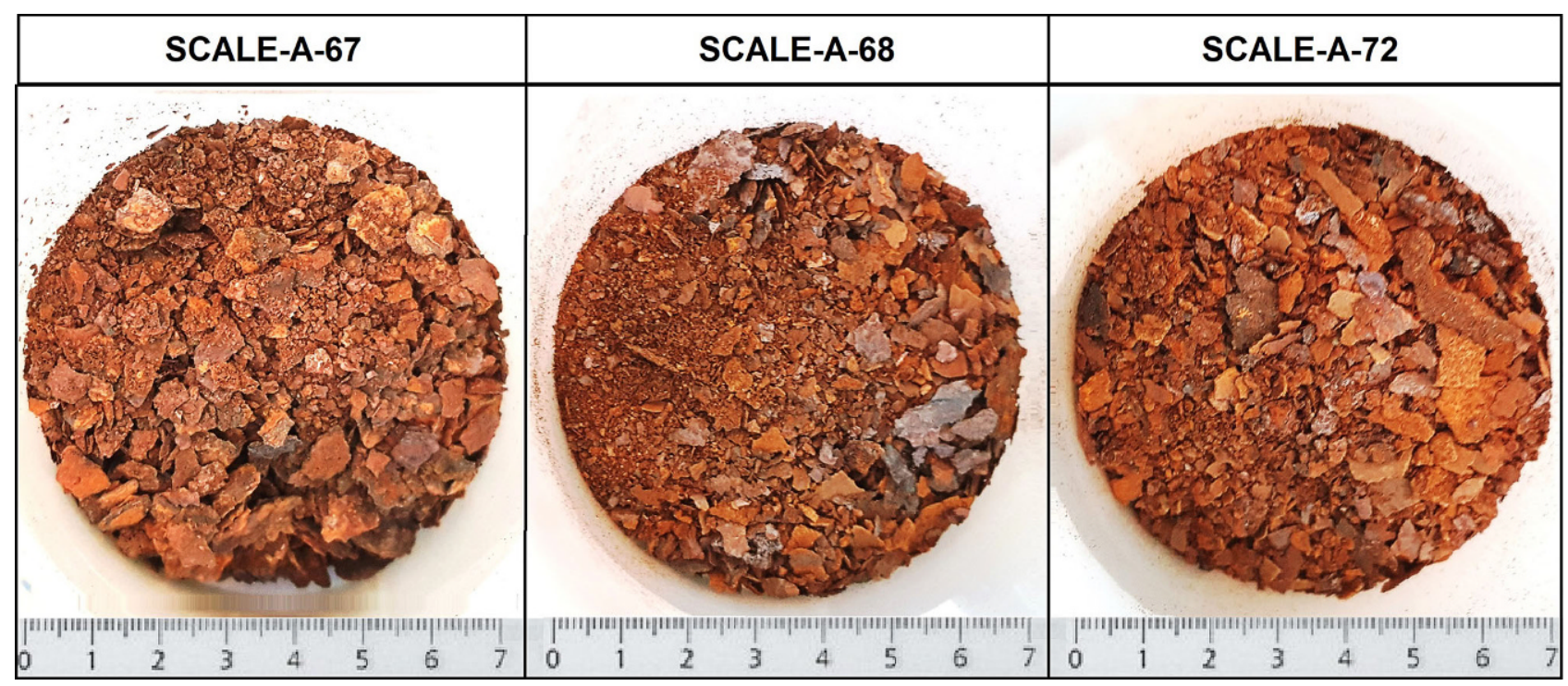

Fig. 6: Visual appearance of the scale samples A-67, A-68 and A-72

\subsection{Chemical Analysis and Mineralogical Interpretation}

In addition to a radiological examination, a chemical analysis of all relevant metals is essential for complete characterization.

\subsubsection{Visual Pre-examination of Selected Scale Samples}

The visual appearance of the same three samples analyzed by HPGe (A-67, A-68 and A-72) is shown in Fig. 6. Iron, mainly from the corrosion of steel, is the dominating metal, which is also reflected in the analysis results (Table 7). The matrix of the scale is carbonate, mainly ferrous carbonate such as antiferromagnetic siderite $\mathrm{FeCO}_{3}$. A minor fraction appears to be goethite $(\alpha-\mathrm{FeOOH})$ which was not fully migrated into the existing carbonate matrix. Radium exists mainly as radium carbonate, namely as Ra-Ba-carbonate, and to a minor extent also Ra-Ba-sulfate which is overgrown/embedded within the mentioned Iron(II)-carbonate matrix.

\subsubsection{Inductively Coupled Plasma-Mass Spectrometric Analysis (ICP-MS)}

Scale samples A-67, A-68 and A-72 were also undergoing a full semiquantitative multi-element metal and metalloid analysis by 'Inductively Coupled Plasma Mass Spectrometry (ICP MS)' at 'Laboratori Nazionali del Gran Sasso' (Tables 6, 7 and 8).

With regard to the quantitative analysis, the instrument was calibrated using a certified standard solution containing $10 \mathrm{ppb}$ of $\mathrm{Li}, \mathrm{Y}, \mathrm{Ce}, \mathrm{TI}$. The uncertainty in this working mode (semi-quantitative analysis) is about $30 \%$ of the given concentration values. A reagent blank was also measured and its signal was subtracted from the sample signals. The results are shown in Table 7. The concentration values refer to solid dry samples.

The clearly demonstrated existence of transition metals such as copper, lead and vanadium in the analyzed scale (Table 7), allows conclusions to be drawn towards uranovanadates (see Table 1) as being a possible source. Table 9 shows estimates of the order of magnitude of relevant uranium-transition metal ratios calculated from Tables 7 and 8 and relates to the entire uranium analyzed.

Compared to relevant minerals [51]:

- Carnotite $\mathrm{K}_{2}\left(\mathrm{UO}_{2}\right)_{2}\left(\mathrm{VO}_{4}\right)_{2} \cdot 3 \mathrm{H}_{2} \mathrm{O}$ has a vanadium-uranium ratio of 1:4.67,

- Sengierite $\mathrm{Cu}_{2}\left(\mathrm{UO}_{2}\right)_{2}\left(\mathrm{VO}_{4}\right)_{2}(\mathrm{OH})_{2} \cdot 6 \mathrm{H}_{2} \mathrm{O}$ has a copperuranium ratio of $1: 3.75$,

- Curienite $\mathrm{Pb}\left(\mathrm{UO}_{2}\right)_{2}\left(\mathrm{VO}_{4}\right)_{2} \cdot 5 \mathrm{H}_{2} \mathrm{O}$ has a lead-uranium ratio of $1: 2.30$.

An exact assignment to individual transition metals or minerals is not directly possible. However, this comparison indicates a possible trend and shows an apparently good match for sengierite, whilst carnotite seems not to be the only possible source for vanadium and the appearance of lead can be allocated to curienite, because the lead-uranium ratio of the mineral is fitting into the lead-uranium ratio of the scale samples.

\subsubsection{Uranium Isotopic Ratio Measurements}

To perform $U$ isotopic measurements, the same solution had been analyzed. The instrumental mass bias was corrected by $50 \mathrm{ppb}$ of natural uranium isotopic reference material (IRMM-3184). (Table 10).

The abundance ratio of the isotopes $\left({ }^{235} \mathrm{U} /{ }^{238} \mathrm{U}\right)$ as a natural rule is 7.257E-03 [60]. The resulting ratio for the reference material in Table 10 of 7.262E-03 demonstrates good agreement and acceptable accuracy. 


\begin{tabular}{|c|c|c|c|c|c|c|c|}
\hline \multicolumn{8}{|c|}{$\begin{array}{l}\text { TABLE } 7 \\
\text { Semiquantitative analysis of metals and metalloids by ICP-MS }\end{array}$} \\
\hline & $\begin{array}{l}\text { SCALE-A-67 } \\
{[p p b]}\end{array}$ & $\begin{array}{l}\text { SCALE-A-68 } \\
{[\mathrm{ppb}]}\end{array}$ & $\begin{array}{l}\text { SCALE-A-72 } \\
{[\mathrm{ppb}]}\end{array}$ & & $\begin{array}{l}\text { SCALE-A-67 } \\
{[\mathrm{ppb}]}\end{array}$ & $\begin{array}{l}\text { SCALE-A-68 } \\
{[\mathrm{ppb}]}\end{array}$ & $\begin{array}{l}\text { SCALE-A-72 } \\
{[\mathrm{ppb}]}\end{array}$ \\
\hline $\mathrm{Fe}$ & $2.1 E+08$ & $2.9 E+08$ & $3.2 E+08$ & $\mathrm{Li}$ & $4.3 E+04$ & $2.5 E+04$ & $1.7 E+04$ \\
\hline $\mathrm{Sr}$ & $8.6 \mathrm{E}+07$ & $2.1 \mathrm{E}+07$ & $4.0 \mathrm{E}+04$ & $\mathrm{Sb}$ & $8.4 \mathrm{E}+03$ & $1.0 \mathrm{E}+04$ & $2.8 \mathrm{E}+03$ \\
\hline $\mathrm{Ca}$ & $5.3 E+07$ & $1.7 \mathrm{E}+07$ & $7.0 \mathrm{E}+06$ & $\mathrm{Ge}$ & $6.7 \mathrm{E}+03$ & $9.5 \mathrm{E}+03$ & $9.5 E+03$ \\
\hline $\mathrm{Ba}$ & $7.2 E+06$ & $7.0 \mathrm{E}+06$ & $7.3 E+04$ & B & $1.0 \mathrm{E}+04$ & $6.4 \mathrm{E}+03$ & $4.8 E+03$ \\
\hline $\mathrm{Mn}$ & $2.2 \mathrm{E}+06$ & $3.0 E+06$ & $4.0 E+06$ & $\mathrm{Rb}$ & $8.4 \mathrm{E}+02$ & 1.1E +03 & $1.0 \mathrm{E}+03$ \\
\hline $\mathrm{Cr}$ & $5.6 \mathrm{E}+06$ & $1.5 \mathrm{E}+06$ & $5.1 E+05$ & $\mathrm{Ce}$ & $9.0 \mathrm{E}+02$ & $8.1 E+02$ & $3.1 \mathrm{E}+02$ \\
\hline $\mathrm{Mg}$ & $2.3 \mathrm{E}+06$ & $1.1 \mathrm{E}+06$ & $2.3 \mathrm{E}+06$ & $\mathrm{La}$ & $6.2 \mathrm{E}+02$ & $6.4 \mathrm{E}+02$ & $1.8 \mathrm{E}+02$ \\
\hline $\mathrm{Zn}$ & $1.5 E+06$ & $6.8 \mathrm{E}+05$ & $1.7 \mathrm{E}+05$ & $\mathrm{Eu}$ & $5.8 \mathrm{E}+02$ & $5.5 \mathrm{E}+02$ & $<21.00$ \\
\hline $\mathrm{Cu}$ & $5.9 E+05$ & $5.4 \mathrm{E}+05$ & $7.2 \mathrm{E}+04$ & $Y$ & $1.0 \mathrm{E}+03$ & $4.7 \mathrm{E}+02$ & $1.6 \mathrm{E}+02$ \\
\hline $\mathrm{Al}$ & $5.7 \mathrm{E}+05$ & $5.3 E+05$ & $4.1 E+05$ & Th & 1.7E +02 & $1.5 \mathrm{E}+02$ & 1.1E +02 \\
\hline$U$ & $6.8 \mathrm{E}+05$ & $4.9 \mathrm{E}+05$ & $6.8 \mathrm{E}+05$ & $\mathrm{Gd}$ & $1.5 \mathrm{E}+02$ & $1.4 \mathrm{E}+02$ & $<68.00$ \\
\hline $\mathrm{Ga}$ & $3.1 \mathrm{E}+05$ & $3.1 \mathrm{E}+05$ & $5.7 \mathrm{E}+03$ & $\mathrm{Bi}$ & $2.4 \mathrm{E}+02$ & $1.3 \mathrm{E}+02$ & $9.9 \mathrm{E}+01$ \\
\hline $\mathrm{Ni}$ & $2.6 \mathrm{E}+05$ & $3.1 E+05$ & $1.2 \mathrm{E}+05$ & $\mathrm{Sm}$ & $1.0 \mathrm{E}+02$ & $1.2 \mathrm{E}+02$ & $<81.00$ \\
\hline $\mathrm{Na}$ & $6.5 \mathrm{E}+05$ & $2.8 \mathrm{E}+05$ & $3.9 E+05$ & $\mathrm{Pr}$ & $9.5 \mathrm{E}+01$ & $1.0 \mathrm{E}+02$ & $3.0 \mathrm{E}+01$ \\
\hline K & $2.7 \mathrm{E}+05$ & $2.3 \mathrm{E}+05$ & $2.4 \mathrm{E}+05$ & $\mathrm{Ag}$ & $1.6 \mathrm{E}+02$ & $8.5 \mathrm{E}+01$ & $4.3 \mathrm{E}+01$ \\
\hline V & $2.6 \mathrm{E}+05$ & $2.2 \mathrm{E}+05$ & $2.2 \mathrm{E}+05$ & Cs & $2.9 \mathrm{E}+01$ & $5.1 \mathrm{E}+01$ & $8.8 \mathrm{E}+01$ \\
\hline $\mathrm{Se}$ & $2.2 \mathrm{E}+05$ & $1.9 \mathrm{E}+05$ & $1.6 \mathrm{E}+05$ & $\mathrm{Ho}$ & $1.1 \mathrm{E}+01$ & $1.1 \mathrm{E}+01$ & $<10.00$ \\
\hline Co & $1.4 \mathrm{E}+05$ & $1.4 \mathrm{E}+05$ & $2.4 \mathrm{E}+05$ & $\mathrm{Er}$ & $3.9 \mathrm{E}+01$ & $<34.00$ & $<32.00$ \\
\hline As & $6.9 E+04$ & $1.0 \mathrm{E}+05$ & $2.1 E+04$ & $\mathrm{Sc}$ & $<2000$ & $<2000$ & $<2000$ \\
\hline Mo & $5.6 \mathrm{E}+04$ & $9.5 \mathrm{E}+04$ & $1.8 \mathrm{E}+04$ & $\mathrm{Cd}$ & $<170.0$ & $<180.0$ & $4.7 \mathrm{E}+02$ \\
\hline $\mathrm{Pb}$ & $5.2 \mathrm{E}+04$ & $7.1 \mathrm{E}+04$ & $1.9 \mathrm{E}+05$ & $\mathrm{~Tb}$ & $1.7 \mathrm{E}+01$ & $<10.00$ & $<10.00$ \\
\hline
\end{tabular}

\section{TABLE 8}

Total thorium and total uranium analyzed by ICP-MS

\begin{tabular}{llll} 
& SCALE-A-67 & SCALE-A-68 & SCALE-A-72 \\
\hline Th $[\mathrm{ppm}]$ & 0.19 & 0.13 & 0.12 \\
\hline$U[\mathrm{ppm}]$ & 740 & 470 & 700 \\
\hline
\end{tabular}

The concentration values refer to the solid samples the uncertainty is about $30 \%$ of the given values

TABLE 9

Uranium-transition metal ratios calculated from Tables 7 and 8

\begin{tabular}{|llll}
\hline & Vanadium -Uranium & Copper-Uranium & Lead-Uranium \\
\hline SCALE-A-67 & $1: 2.62$ up to 2.69 & $1: 1.15$ up to 1.19 & $1: 13.00$ up to 13.45 \\
\hline SCALE-A-68 & $1: 2.14$ up to 2.23 & $1: 0.87$ up to 0.91 & $1: 6.62$ up to 6.90 \\
\hline SCALE-A-72 & $1: 3.10$ up to 3.36 & $1: 9.44$ up to 10.29 & $1: 3.58$ up to 3.89 \\
\hline Average & $1: 2.69$ & $1: 3.97$ & $1: 7.91$ \\
\hline
\end{tabular}

TABLE 10

U Isotopic composition measured in the scale samples

\begin{tabular}{llll}
\hline & ${ }^{234} \mathrm{U} /$ Tot $[\%]$ & ${ }^{235} \mathrm{U} /$ Tot $[\%]$ & ${ }^{238} \mathrm{U} /$ Tot $[\%]$ \\
\hline SCALE-A-67 & $0.0055 \pm 0.0003$ & $0.711 \pm 0.010$ & $99.28 \pm 0.02$ \\
\hline SCALE-A-68 & $0.0058 \pm 0.0005$ & $0.715 \pm 0.010$ & $99.28 \pm 0.03$ \\
\hline SCALE-A-72 & $0.0059 \pm 0.0003$ & $0.714 \pm 0.010$ & $99.28 \pm 0.02$ \\
\hline IRMM-3184 & 0.0052752 & 0.72096 & 99.27376 \\
\hline
\end{tabular}




\section{Summary and Outlook}

In the course of this study, it was proven several times by radiological and chemical analysis that uranium definitely exists in NORM-bearing mineral scales. The highest specific activity of ${ }^{238} \mathrm{U}$ analyzed in the subject scale samples with gamma spectroscopy was $11.4[\mathrm{~Bq} / \mathrm{g}]$ and supplementary chemical analysis has shown concentrations of total uranium of up to $740 \mathrm{ppm}$, which is still far below the exploitable limit of uranium mines. However, the technical term 'uranium scale' is justified.

The very likely existence of uranovanadates such as carnotite $\mathrm{K}_{2}\left(\mathrm{UO}_{2}\right)_{2}\left(\mathrm{VO}_{4}\right)_{2} \cdot 2-3 \mathrm{H}_{2} \mathrm{O}$ and other minerals of the carnotite group and related species as a typical appearance of calcrete hosted uranium deposits and their increased aqueous solubility in carbonate environments are considered a possible source for the generation of 'uranium scale' in oil production equipment from the Lower Cretaceous Carbonate Formations in the Middle East.

Based on the results of this study, scale removal from tubulars and equipment (descaling), which is a relevant issue in the oil and gas industry, is not possible with chemical solvents or acids owing to the insoluble siderite matrix of the scale. Consequently, wet-mechanic pipe cleaning technologies may be applied such as high-pressure jet cleaning either with or without supportive abrasives. Processing of NORM scale after removal from the equipment with the typical technologies known from ore processing such as milling and flotation [61] is conceivable, but currently fails due to low available quantities and economic viability as well as the lack of recycling and disposal options for the generated waste streams.

Funding. Open access funding provided by Montanuniversität Leoben.

Open Access This article is licensed under a Creative Commons Attribution 4.0 International License, which permits use, sharing, adaptation, distribution and reproduction in any medium or format, as long as you give appropriate credit to the original author(s) and the source, provide a link to the Creative Commons licence, and indicate if changes were made. The images or other third party material in this article are included in the article's Creative Commons licence, unless indicated otherwise in a credit line to the material. If material is not included in the article's Creative Commons licence and your intended use is not permitted by statutory regulation or exceeds the permitted use, you will need to obtain permission directly from the copyright holder. To view a copy of this licence, visit http://creativecommons.org/licenses/by/4.0/.

\section{References}

1. W. A. Kolb and M. Wojcik, "Enhanced radioactivity due to natural oil and gas production and related radiological problems," Sci. Total Environ., vol. 45, pp. 77-84, Oct. 1985

2. T. F. Gesell, "Occupational Radiation Exposure Due to $222 \mathrm{Rn}$ in Natural Gas and Natural Gas Products," Health Phys., vol. 29, no. 5, p. 681 , Nov. 1975

3. J. C. McLennan, "The Radioactivity of Mineral Oils and Natural Gases," in Transactions of the International Electrical Congress, St. Louis, 1904, St. Louis: [Albany, N.Y., J.B. Lyon Company], 1904, pp. 398-422

4. I. M. Waldram, "Natural Radioactive Scale: The Development of Safe Systems of Work," J. Pet. Technol., vol. 40, pp. 1057-1060, Aug. 1988
5. A. Khodashenas, E. Roayaei, S. M. Abtahi, and E. Ardalani, “Evaluation of Naturally Occurring Radioactive Materials (NORM) in the South Western Oil Wells of Iran," J. Environ. Radioact., vol. 109, pp. 71-75, Jul. 2012

6. IAEA, "Radiation Protection and the Management of Radioactive Waste in the Oil and Gas Industry," Safety Reports Series No. 34, 2003

7. IAEA, “Extent of Environmental Contamination by Naturally Occurring Radioactive Material (NORM) and Technological Options for Mitigation," Technical Reports Series No. 419, 2003

8. S. Landsberger, D. Tamalis, C. Leblanc, and M.D. Yoho, “Disequilibrium in the uranium and actinium series in oil scale samples", Journal of Environmental Radioactivity, vol. 166, pp. 126-129, Jan. 2017. https://doi.org/10.1016/j.jenvrad.2016.03.026.

9. M. H. Paranhos Gazineu, A. A. de Araújo, Y. B. Brandão, C. A. Hazin, and J. M. de O. Godoy, "Radioactivity concentration in liquid and solid phases of scale and sludge generated in the petroleum industry," J. Environ. Radioact., vol. 81, no. 1, pp. 47-54, Jan. 2005

10. S. Shawky, H. Amer, A. A. Nada, T. M. Abd El-Maksoud, and N. M. Ibrahiem, "Characteristics of NORM in the oil industry from Eastern and Western deserts of Egypt," Appl. Radiat. Isot., vol. 55, no. 1, pp. 135-139, Jul. 2001

11. International Association of Oil \& Gas Producers, "Guidelines for the management of Naturally Occurring Radioactive Material (NORM) in the oil \& gas industry," IOGP bookstore, 2008

12. G. Rajaretnam and H. B. Spitz, "Effect of leachability on environmental risk assessment for naturally occurring radioactive materials in petroleum oil fields," Health Phys., vol. 78, no. 2, pp. 191-198, Feb. 2000

13. K. P. Smith, D. L. Blunt, G. P. Williams, and C. L. Tebes, “Radiological Dose Assessment Related to Management of Naturally Occurring Radioactive Materials Generated by the Petroleum Industry," p. 77, 1996

14. J. M. Godoy and R. Petinatti da Cruz, "226Ra and $228 \mathrm{Ra}$ in scale and sludge samples and their correlation with the chemical composition," J. Environ. Radioact., vol. 70, no. 3, pp. 199-206, Jan. 2003

15. B. J. S. Varaprasad and G. K. Viswanadh, "A Study on scale formation in water distribution systems," Int. J. Water Resour. Environ. Manag., vol. 3, no. 1, pp. 129-136, 2012

16. G. Xhixha et al., "A century of oil and gas exploration in Albania: Assessment of Naturally Occurring Radioactive Materials (NORMs)," Chemosphere, vol. 139, pp. 30-39, Nov. 2015

17. N. Awwad, "Overview about Different Approaches of Chemical Treatment of NORM and TE-NORM Produced from Oil Exploitation," in Advances in Petrochemicals, V. Patel, Ed. Rijeka: InTech, 2015

18. T. Zhang, K. Gregory, R. W. Hammack, and R. D. Vidic, “Co-precipitation of Radium with Barium and Strontium Sulfate and Its Impact on the Fate of Radium during Treatment of Produced Water from Unconventional Gas Extraction," Environmental Science \& Technology, vol. 48 (8), pp. 4596-4603, 2014

19. G. Xhixha et al., “The worldwide NORM production and a fully automated gamma-ray spectrometer for their characterization," J. Radioanal. Nucl. Chem., vol. 295, no. 1, pp. 445-457, Jan. 2013

20. J. A. Veil, "Update on cavern disposal of NORM-contaminated oil field wastes." Ground Water Protection Council 98 Annual Forum, Sacramento, CA (US), 09/19/1998-09/23/1998. 22-Sep-1998

21. S. B. Samat, S. Green, and A. H. Beddoe, "The ${ }^{40} \mathrm{~K}$ activity of one gram of potassium," Phys. Med. Biol., vol. 42, no. 2, p. 407, 1997

22. A. N. Al-Farsi, Radiological Aspects of Petroleum Exploration and Production in the Sultanate of Oman. Queensland University of Technology, Brisbane, 2008

23. I. F. Vincent-Akpu, B. B. Babatunde, and P. E. Ndimele, “Chapter 11-Occurrence of Radioactive Elements in Oil-Producing Region of Nigeria," in The Political Ecology of Oil and Gas Activities in the Nigerian Aquatic Ecosystem, Academic Press, 2018, pp. 149-158

24. R. B. Richter and P. Hosemann, "The treatment and disposal of natural radioactive waste from the oil and natural gas industry-potentials and limitations, Part 1," AT Miner. Process., vol. 9, pp. 58-71, 2012 
25. R. B. Richter and P. Hosemann, "The treatment and disposal of natural radioactive waste from the oil and natural gas industry-potentials and limitations, Part 2," AT Miner. Process., vol. 11 , pp. $61-69,2012$

26. J. A. Abdullah, M. S. Al-Masri, Y. Amin, H. Khalily, M. Ammar, and S. Nassour, "An innovative procedure for NORM scales treatment and radionuclides separation," Appl. Radiat. Isot., vol. 125, pp. 139-143, Jul. 2017

27. C. T. Lehmann, K. I. Mohamed, D. O. Cobb and A. Al Hendi, “RockTyping of Upper Jurassic (Arab) Carbonates Offshore Abu Dhabi". Society of Petroleum Engineers. https://doi.org/10.2118/117889-MS, 2008

28. A. S. Alsharhan and K. Magara, "Nature and Distribution of Porosity and Permeability in Jurassic Carbonate Reservoirs of the Arabian Gulf Basin", Facies Volume 32, Issue 1, pp 237-253, 1995. https://doi. org/10.1007/BF02536872

29. T. H. Hassan and Y. Wada, "Geology and Development of Thamama Zone 4, Zakum Field". Society of Petroleum Engineers. https://doi. org/10.2118/7779-PA, 1981

30. A. S. Alsharhan, “Geology and reservoir characteristics of Lower Cretaceous Kharaib Formation in Zakum Field, Abu Dhabi, United Arab Emirates", Geological Society London Special Publications 50(1), pp. 299-316, 1990

31. R. S. Fisher, "Naturally Occurring Radioactive Material (NORM) in Produced Water and Scale from Texas Oil, Gas, and Geothermal Wells: Geographic, Geologic, and Geochemical Controls", Geological Circular 95-3, Bureau of Economic Geology, The University of Texas at Austin, 1995

32. IAEA, "Assessing the Need for Radiation Protection Measures in Work involving Minerals and Raw Materials," Safety Reports Series No. 49, 2006

33. I. Puigdomenech, Hydra/Medusa Chemical Equilibrium Database and Plotting Software, KTH Royal Institute of Technology, 2004. https://www.kth.se/che/medusa/downloads-1.386254

34. A. Krestou and D. Panias, "Uranium (VI) speciation diagrams in the $\mathrm{UO}_{2}{ }^{2+} / \mathrm{CO}_{3}{ }^{2-} / \mathrm{H}_{2} \mathrm{O}$ system at $25^{\circ} \mathrm{C}^{\prime \prime}$, the European Journal of Mineral Processing and Environmental Protection Vol. 4, No. 2, 1304-0868, pp. 113-129, 2004

35. D. Gorman-Lewis, P. C Burns and J. B. Fein, "Review of uranyl mineral solubility measurements", Journal of Chemical Thermodynamics 40(3), pp. 335-352, 2008

36. A. W. Mann, “Calculated Solubilities of some Uranium and Vanadium Compounds in Pure and Carbonated Waters, as a Function of pH", CSIRO Report No. FP. 6, CSIRO Mineral Research Laboratories, Division of Mineralogy, Sept. 1974. https://inis.iaea.org/search/ search.aspx?orig_q=RN:6217378

37. IAEA, "Surficial Uranium Deposits", Report on the Working Group on Uranium Geology organized by the International Atomic Energy Agency (IAEA-TECDOC-322), Vienna, 1984

38. USGS, "Assessment of Undiscovered Resources in Calcrete Uranium Deposits, Southern High Plains Region of Texas, New Mexico, and Oklahoma", 2017, Fact Sheet 2017-3078, 2017

39. J. A. Kinnaird and A. m. Nex, "Uranium in Africa", Episodes, Vol. 39, No. 2, pp 335-359, 2016

40. H. N. Khoury, "Geochemistry of Surficial Uranium Deposits from Central Jordan", Jordan Journal of Earth and Environmental Sciences, Vol. 6, pp 11-22, 2014

41. S. Liu and S. Jaireth, "Exploring for calcrete-hosted uranium deposits in the Paterson region, Western Australia", AUSGEO, Issue 103, pp. 1-5, Sept. 2011

42. A. D. Weeks and M.E. Thompson, "Identification and Occurrance of Uranium and Vanadium Minerals from the Colorado Plateaus", Geological Survey Bulletin 1009-B, 1954. https://doi.org/10.3133/b1009B

43. S. V. Krivovichev and J. Plášil, "Mineralogy and crystallography of uranium", in: P.C. Burns and G.E. Sigmon (eds.) Uranium: From Cradle to Grave. Mineralogical Association of Canada Short Courses 43: pp 15-119, 2013
44. E. Z. Buryanova, G. S. Strokova and V. A. Shitov, “Vanuranylite, a new mineral", Zapiski Vses. Mineralog. Obshch. 94, (in Russian), pp 437-443, 1965

45. H. N. Koury, E. M. Salameh and L. D. Clark, Mineralogy and origin of surficial uranium deposits hosted in travertine and calcrete from central Jordan, Applied Geochemistry 43, pp pp 49-65, 2014

46. B. Pracejus, N. S. Rajan, S. Al-Khirbash, T. Al-Hosni, A. Ebrahimi, S. Al-Bulushi, A. Al-Lazki and M. Al-Maashani, "Aspects of U-Th Fractionation in Tertiary Limestones and Calcretes of Dhofar, Southern Oman", Chemie der Erde/Geochemistry, in print, 2018. https://doi. org/10.1016/j.chemer.2018.09.003

47. M. S. Ayub, "Solubility of carnotite in carbonated waters". Proceed ings of the MINT R and D Seminar 2004: Innovation through excellence in R and D, Seminar A, (p. 291). Malaysia: Malaysian Inst for Nuclear Technology Research MINT, 2004

48. E. M. Wylie and P. C. Burns, Crystal structures of six new uranyl selenite and selenite compounds and their relationship with uranyl mineral structures, Can. Mineral (50), pp 147-157, 2012

49. M. V. Charykova, V. G. Krivovichev, O. S. Yakovenko, V. V. Semenova, K. N. Semenov and W. Depmeier, "Thermodynamics of arsenates, selenites, and sulfates in the oxidation zone of sulfide ores: VI. Solubility of synthetic analogs of ahlfeldite and cobaltomenite at $25^{\circ} \mathrm{C}$., Geol. Ore. Depos. 54, pp 638-646, 2012

50. V. V. Gurzhiy, O. S. Tyumentseva, I.V. Kornyakov, S. V. Krivovichev and I. G. Tananaev, "The role of potassium atoms in the formation of uranyl selenates: the crystal structure and synthesis of two novel compounds", Journal of Geosciences, 59, pp 123-133, 2014

51. Mineralogy Data Base (by David Barthelmy): http://www.webmineral. com/data/, 2019

52. “GENT4 | geant4.web.cern.ch.” [Online]. Available: https://geant4. web.cern.ch/, 2016

53. A. Dosseto, B. Bourdon, J. Gaillardet, L. Maurice-Bourgoin, and C. J. Allègre, "Weathering and transport of sediments in the Bolivian Andes: Time constraints from uranium-series isotopes," Earth Planet. Sci. Lett., vol. 248, no. 3, pp. 759-771, Aug. 2006

54. M. Omar, M. S. Hamzah, and A. K. Wood, "Radioactive disequilibrium and total activity concentration of NORM waste," J. Nucl. Relat. Technol., vol. 5, no. 2, pp. 47-56, 2008

55. A. Papadopoulos, G. Christofides, A. Koroneos, S. Stoulos, and C. Papastefanou, "Radioactive secular equilibrium in $238 \mathrm{U}$ and 232Th series in granitoids from Greece," Appl. Radiat. Isot., vol. 75, pp. 95-104, May 2013

56. H. Yücel, M. A. Çetiner, and H. Demirel, “Use of the $1001 \mathrm{keV}$ peak of $234 \mathrm{mPa}$ daughter of $238 \mathrm{U}$ in measurement of uranium concentration by HPGe gamma-ray spectrometry," Nucl. Instrum. Methods Phys. Res. Sect. Accel. Spectrometers Detect. Assoc. Equip., vol. 413, no. 1, pp. 74-82, Aug. 1998

57. N. Q. Hung, H. D. Chuong, L. Q. Vuong, T. T. Thanh, and C. V. Tao, "Intercomparison $295 \mathrm{Nal}(\mathrm{TI})$ and HPGe spectrometry to studies of natural radioactivity on geological 296 samples," J. Environ. Radioact., vol. 164, pp. 197-201, Nov. 2016

58. V. Peyres, T. Crespo, M. Mejuto, and E. García-Toraño, “Measurement of NORM samples with CeBr3 detectors," Appl. Radiat. Isot., vol. 126, pp. 307-310, Aug. 2017

59. IOGP, Managing Naturally Occuring Radioactive Material (NORM) in the Oil and Gas Industry (Report 412), 2016

60. C. Liu, B. Hu, J. Shi, J. Li, X. Zhang, and H. Chen, “Determination of uranium isotopic ratio $\left({ }^{235} \mathrm{U} /{ }^{238} \mathrm{U}\right)$ using extractive electrospray ionization tandem mass spectrometry", J. Anal. Atom. Spectrom., 26, pp. 2045-2051, 2011

61. Yarar, B. and Richter, R.B., "Flotation". In "Ullmann's Encyclopedia of Industrial Chemistry", (Ed.). Wiley Online Library, 2016. https:// doi.org/10.1002/14356007.b02_23.pub2

Publisher's Note. Springer Nature remains neutral with regard to jurisdictional claims in published maps and institutional affiliations. 